
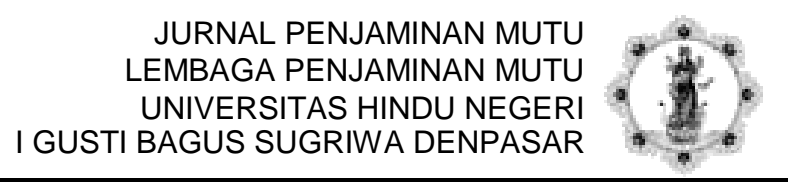

Volume 7 Nomor 22021

ISSN : 2407-912X (Cetak)

ISSN : 2548-3110 (Online)

http://ejournal.ihdn.ac.id/index.php/JPM

\title{
PENDIDIKAN AGAMA DAN KEAGAMAAN DALAM MENUNJANG MUTU PENDIDIKAN DI INDONESIA
}

\author{
Oleh \\ I Nyoman Temon Astawa \\ Universitas Hindu Negeri I Gusti Bagus Sugriwa Denpasar \\ temonastawa@gmail.com
}

diterima 25 Juli 2021, direvisi 25 Agustus 2021, diterbitkan 31 Agustus 2021

\begin{abstract}
Religious education and religious education have very strong legal force, religious schools that are under the auspices of the Indonesian Ministry of Religion and public schools that are under the auspices of the Indonesian Ministry of Education are still a type of belief, and both formally and legally equal in law. The development of religious and religious education in schools refers to Government Regulation No. 19 of 2005 concerning National Education Standards, especially on content standards, learning process standards, educator standards and education staff, and educational facilities and infrastructure. The development of religious education also implements Government Regulation Number 55 of 2007 concerning Religious Education and Religious Education.
\end{abstract}

\section{Keywords : Religious Education, Religion And Public Schools}

\section{PENDAHULUAN}

Pendidikan merupakan sebuah proses dan sekaligus sistem yang bermuara pada pencapaian tujuan tertentu yang dinilai dan diyakini sebagai yang paling ideal. Bagi bangsa Indonesia tujuan ideal yang hendak dicapai lewat proses dan sistem pendidikan nasional ialah sebagaimana yang telah dituangkan dalam Undang-Undang Sistem Pendidikan Nasional No.20 Tahun 2003 Bab II Pasal 4 : "Pendidikan Nasional bertujuan mencerdaskan kehidupan bangsa dan mengembangkan manusia Indonesia seutuhnya, yaitu manusia yang beriman dan bertakwa terhadap Tuhan Yang Maha Esa dan berbudi pekerti luhur, memiliki pengetahuan dan keterampilan, kesehatan jasmani dan rohani, kepribadian dan mandiri serta bertanggung jawab pada kemasyarakatan dan kebangsaan".

Sebagai usaha untuk mengimplementasika dari UU Sitem Pendidikan Nasional tersebut, dengan ini pemerintah memberikan perhatian yang sangat besar terhadap Pendidikan agama. Mengingat agama mempunyai peranan yang sangat penting dalam kehidupan manusia. Agama merupakan tata nilai, pedoman, 
pembimbing, dan pendorong manusia untuk mencapai kualitas hidupnya yang lebih baik dan sempurna.

Bagi bangsa Indonesia, agama merupakan tenaga penggerak yang sangat tinggi nilainya bagi pengisian aspirasi aspirasi bangsa. Sebagaimana tercermin dalam tujuan pendidikan nasional yang muwujudkan insan yang bertakwa : ketakwaan kepada Tuhan Yang Maha Esa merupakan tujuan pendidikan nasional dalam rangka pengembangan bangsa dan budaya bangsa. Untuk mencapai tujuan tersebut pendidikan agama diberikan kepada semua jenis, tingkat (jenjang) dan jalur sekolah baik negeri maupun swasta. Selain itu, pendidikan nasional merupakan komponen pendidikan dalam kurikulum sekolah - sekolah sejak taman kanak-kanak hingga pendidikan tinggi, dengan bobot kredit yang cukup.

Untuk mewujudkan insan yang bertaqwa tonggak utamanya adalah dengan menerapkan Pendidikan agama di segala lini kehidupan dan jenjang pendidikan. Karena pendidikan agama berfungsi membentuk manusia Indonesia yang beriman dan bertakwa kepada Tuhan Yang Maha Esa serta berakhlak mulia dan mampu menjaga kedamaian dan kerukunan hubungan inter dan antar umat beragama.

Dengan modal Pendidikan agama yang kuat, akan membentuk kepribadian yang handal dan professional, tentunya dalam mengembangkan dan meningkatkan kemampuan dari peserta didik dalam memahami, menghayati dan mengamalkan nilai-nilai agama yang menyerasikan penguasaannya dalam ilmu pengetahuan, teknologi dan seni.

Di Indonesia pendidikan terasa ada dikotomi, terbukti dengan adanya perhelatan dualisme sistem pendidikan di Indonesia, yakni antara satuan pendidikan madrasah yang bernaung pada Kementerian Agama RI dan Sekolah umum yang bernaung pada Kementerian Pendidikan RI masih menjadi suatu keniscayaan. Walaupun keduanya secara yuridis formal memiliki kesamaan derajat di mata hukum namun masih menimbulkan "image" dalam masyarakat.
Disadari maupun tidak, di kalangan masyarakat masih menganggap bahwa madrasah sebagai lembaga pendidikan yang berada di bawah payung Kementerian Agama RI secara kualitas masih berada di bawah kualitas sekolah umum yang berada di bawah payung Kementerian Pendidikan Nasional RI.

Perbedaan yang masih mencolok antara madrasah dan sekolah-sekolah umum, dapat dilihat dari dua bentuk. Pertama adalah tradisi proses, dimana tradisi proses pembelajaran di madrasah masih memprihatinkan, masih bergaya tradisional dan juga proses pembelajaran masih didominasi oleh para pendidik atau guru yang kualitas tenaga pengajarnya kurang memadai, tenaga pengajar yang mengajarnyapun tidak sesuai dengan keahlian yang dimilikinya. Kedua, akses para alumni terhadap perguruan tinggi dan dunia kerja sangat berbeda, lulusan dari sekolah-sekolah umum memiliki akses yang lebih terbuka untuk masuk ke perguruanperguruan tinggi umum, sementara bagi lulusan madrasah, keterbukaan ini hanya ada pada perguruan-perguruan tinggi . Dari segi akses ke lapangan kerja, tampaknya kalangan dunia usaha lebih mempercayai lulusan sekolah-sekolah umum dari madrasah. Lulusan sekolah-sekolah umum lebih mampu bersaing dengan lulusan dari madrasah.

Setiap permasalahan dalam pendidikan ini merupakan permasalahan yang besar dan ditujukan tidak hanya bagi penulis sendiri namun juga bagi para pemerhati dan pengelola lembaga-lembaga pendidikan khususnya. Penulisan ini juga ingin menjawab mengapa hal ini bisa terjadi, padahal muatan pelajaran umum antara madrasah dengan sekolah umum adalah sama, pada kasus ini sebenarnya madrasah masih memiliki keunggulan karena muatan pendidikan agama jelas lebih banyak dari pada sekolah-sekolah umum, ini berarti pendidikan moral yang dikandung dalam pendidikan agama lebih banyak diberikan pada madrasah. Oleh karena itu penulisan ini sangat penting, yakni untuk mengilangkan label atau image bahwa madrasah sebagai lembaga pendidikan "kelas dua" di tengah-tengah masyarakat. 
Untuk menelusuri seberapa jauh perhatian pemerintah dalam memerankan Pendidikan agama dan keagamaan dalam Undang - undang nomor 20 tahun 2003, dijelaskan beberapa tahapan antara lain : definisi dari pendidikan Agama dan Keagamaan, bagaimana kebijakan pemerintah terhadap pendidikan Agama dan Keagamaan, serta seberapa jauh implementasi Pendidikan Agama dan Keagamaan yang diperankan oleh pemerintah.

\section{PEMBAHASAN}

\subsection{Pengertian Pendidikan Agama dan Keagamaan}

Kata "pendidikan" mengandung pengertian sebagai proses pengubahan sikap dan tata laku seseorang atau kelompok orang dalam usaha mendewasakan manusia melalui upaya pengajaran dan pelatihan, dan bila pengertian tersebut dikaitkan dengan ajaran agama, maka pendidikan adalah sebagai sarana yang paling strategis untuk melahirkan manusia yang terbina seluruh potensi dirinya (fisik, psikis, akal, spiritual, talenta dan sosial) sehingga dapat melaksanakan fungsi pengabdiannya dalam rangka beribadah kepada Tuhan Yang maha esa serta mencapai kebahagiaan hidup di dunia dan akhirat.

Dalam arti yang sederhana pendidikan sering diartikan sebagai usaha manusia untuk membina kepribadiannya sesuai dengan nilainilai di dalam masyarakat dan kebudayaan. Dalam perkembangannya, istilah pendidikan atau paedagogie berarti bimbingan atau pertolongan yang diberikan dengan sengaja oleh orang dewasa. Selanjutnya, pendidikan diartikan sebagai usaha yang dijalankan seseorang atau kelompok orang lain agar menjadi dewasa atau mencapai tingkat hidup atau penghidupannya yang lebih tinggi dalam arti mental.

Dalam bahasa Inggris, education (pendidikan) berasal dari kata educate (mendidik), artinya memberi peringatan (to elicit, to give, to rise), dan mengembangkan (to evolue, to develop). Dalam pengertian yang sempit, education atau pendidikan berarti proses pembuatan untuk memperoleh pengetahuan.
Dalam Undang-Undang Nomor 20 tahun 2003 Bab I Pasal I ayat (1), Pendidikan diartikan sebagai usaha sadar dan terencana untuk mewujudkan suasana belajar dan proses pembelajaran agar peserta didik secara aktif mengembangkan potensi dirinya untuk memiliki kekuatan spiritual keagamaan, pengendalian diri, kepribadian, kecerdasan, akhlak mulia, serta keterampilan yang diperlukan dirinya, masyarakat bangsa dan Negara.

Kendatipun demikian, dalam hal-hal tertentu, memiliki kesamaan makna, namun secara esensial, setiap hal memiliki perbedaan, baik secara tekstual maupun konstekstual. Dengan demikian pendidikan adalah usaha sadar dan terencana untuk mewujudkan suasana belajar dan proses pembelajaran agar peserta didik secara aktif mengembangkan potensi dirinya untuk memiliki kekuatan spiritual keagamaan, pengendalian diri, kepribadian, kecerdasan, akhlak mulia, serta keterampilan yang diperlukan dirinya, masyarakat, bangsa dan negara.

Selanjutnya Kata "agama” dalam kamus Ilmiah Populer "agama" diartikan sebagai keyakinan dan kepercayaan kepada Tuhan; akidah, din (ul). Pendidikan agama adalah pendidikan yang memberikan pengetahuan dan membentuk sikap, kepribadian, dan keterampilan peserta didik dalam mengajarkan ajaran agamanya, yang dilaksanakan sekurang-kurangnya melalui mata pelajaran/kuliah pada semua jalur, jenjang, dan jenis pendidikan.

Sedangkan "Keagamaan" merupakan kata sifat dari "agama". Sehingga keagamaan berarti memahami dan mengamalkan nTilainilai ajaran agama.

Dalam Peraturan Pemerintah RI No. 55 Tahun 2007 tentang pendidikan agama dan Keagamaan disebutkan pada Bab I Ketentuan Umum pasal 1, dijelaskan bahwa:

1. Pendidikan agama adalah pendidikan yang memberikan pengetahuan dan membentuk sikap, kepribadian, dan keterampilan peserta didik dalam mengamalkan ajaran agamanya, yang dilaksanakan sekurang-kurangnya 
melalui mata pelajaran/kuliah pada semua jalur, jenjang, dan jenis pendidikan.

2. Pendidikan keagamaan adalah pendidikan yang mempersiapkan peserta didik untuk dapat menjalankan peranan yang menuntut penguasaan pengetahuan tentang ajaran agama dan/atau menjadi ahli ilmu agama dan mengamalkan ajaran agamanya.

3. Pendidikan diniyah adalah pendidikan keagamaan yang diselenggarakan pada semua jalur dan jenjang pendidikan.

4. Pesantren atau pondok pesantren adalah lembaga pendidikan keagamaan berbasis masyarakat yang menyelenggarakan pendidikan diniyah atau secara terpadu dengan jenis pendidikan lainnya.

5. Pasraman adalah satuan pendidikan keagamaan Hindu pada jalur pendidikan formal dan nonformal.

6. Pesantian adalah satuan pendidikan keagamaan Hindu pada jalur pendidikan nonformal yang mengacu pada sastra agama dan/atau kitab suci Weda.

7. Pabbajja samanera adalah satuan pendidikan keagamaan Buddha pada jalur pendidikan nonformal.

8. Shuyuan adalah satuan pendidikan keagamaan Khonghucu yang diselenggarakan pada semua jalur dan jenjang pendidikan yang mengacu pada $\mathrm{Si}$ Shu Wu Jing.

9. Tempat pendidikan agama adalah ruangan yang digunakan untuk melaksanakan pendidikan agama.

10. Rumah ibadah adalah bangunan yang secara khusus dibangun untuk keperluan tempat beribadah warga satuan pendidikan yang bersangkutan dan/atau masyarakat umum.

\subsection{Kebijakan Pemerintah Terhadap pendidikan Agama dan Keagamaan}

Undang-undang No.20 Tahun 2003 tentang Sistem Pendidikan Nasional, bahwa secara yuridis formal satuan pendidikan madrasah (kementerian Agama RI) dan sekolah (Kementerian Pendidikan Nasional RI) memiliki kesamaan derajat di mata hukum. Sebagai konsekwensi dari Undang- undang tersebut tentu saja beragam peraturan, seperti Peraturan Pemerintah (PP), Peraturan Menteri Pendidikan Nasional (Permendiknas RI), serta Peraturan Menteri Agama (Permenag RI) sebagai aturan yang secara teknis operasional menjelaskan tentang pendidikan.

Dari hirarki Undang-undang tersebut di atas maka lahirlah PP No. 55 Tahun 2007 tentang pendidikan Agama dan Keagamaan. Sebagaimana dalam Pasal 30 ayat (5), dan Pasal 37 ayat (3), UU Sisdiknas 20 2003, mengamanatkan perlunya menetapkan Peraturan Pemerintah tentang Pendidikan Agama dan Keagamaan. Mengingat pentingnya penjabaran lebih rinci, untuk mempermudah pelaksanaan secara tekhnis sebagai panduan di lapangan, maka tepatnya pada tanggal 5 Oktober 2007, Produk Hukum yang berupa Peraturan Pemerintah (PP) Nomor 55 Tahun 2007, ditetapkan oleh pemerintah yang dalam pengelolaannya sesuai dengan PP 55 2007, Pasal 9 ayat 3, dilakukan oleh Menteri Agama. Dalam Peraturan Pemerintah nomer 55 Tahun 2007 menyebutkan bahwa"Pendidikan keagamaan adalah pendidikan yang mempersiapkan peserta didik untuk dapat menjalankan peranan yang menuntut penguasaan pengetahuan tentang ajaran agama dan/atau menjadi ahli ilmu agama dan mengamalkan ajaran agamanya.

\subsection{Implementasi Pendidikan Agama dan Keagamaan}

Kebijakan dan implementasi tidak dapat dipisahkan, sebuah kebijakan tidak berarti tanpa diimplemetasikan. Carl J. Frederick menyatakan bahwa kebijakan itu adalah serangkaian tindakan seseorang, kelompok atau pemerintah dalam suatu lingkungan tertentu dengan menunjukkan hambatanhambatan dan kesempatan-kesempatan terhadap usulan kebijakan tersebut dalam rangka mencapai tujuan tertentu. Kebijakan juga merupakan arah tindakan yang mempunyai maksud yang ditetapkan oleh seorang aktor dalam mengatasi suatu masalah atau suatu persoalan. 
Definisi tersebut menekankan pentingnya implementasi kebijakan yang dilakukan oleh pemerintah. Dengan pengertian bahwa usaha dalam rangka implementasi kebijakan berarti melakukan pelaksanaan dan pengendalian arah tindakan kebijakan sampai dengan tercapainya hasil kebijakan.

Implementasi Pendidikan Agama dan Keagamaan yang Pada Pasal 30 ayat (1) UU RI Sikdiknas No.20 Th.2003 dijelaskan bahwa "pendidikan Keagamaan diselenggarakan oleh Pemerintah dan/atau kelompok masyarakat dari pemeluk agama, sesuai dengan peraturan perundang undangan". Sebagai bagian dari pendidikan nasional, Pendidikan Agama mempunyai peran yang sangat penting dan strategis dalam rangka mewujudkan fungsi dan tujuan pendidikan nasional. Peraturan Pemerintah No. 55 tahun 2007 tentang Pendidikan Agama dan Pendidikan Keagamaan Pasal 2 ayat (1) secara tegas menyatakan bahwa Pendidikan Agama berfungsi membentuk manusia Indonesia yang beriman dan bertakwa kepada Tuhan Yang Maha Esa serta berakhlak mulia dan mampu menjaga kedamaian dan kerukunan hubungan inter dan antarumat beragama.

Melihat demikian pentingnya Pendidikan Agama di sekolah dan perguruan tinggi sebagaimana dirumuskan dalam peraturan perundang-undangan di atas, maka Pendidikan Agama memainkan peran dan tanggung jawab yang sangat besar dalam ikut serta mewujudkan tujuan pendidikan nasional, terutama untuk mempersiapkan peserta didik dalam memahami ajaran-ajaran agama dan berbagai ilmu yang dipelajari serta melaksanakannya dalam kehidupan seharihari. Pendidikan Agama hendaknya lebih ditekankan untuk mempersiapkan peserta didik agar memiliki budi pekerti atau karakter mulia yang ditunjang dengan penguasaan ilmu dengan baik kemudian mampu mengamalkan ilmunya dengan tetap dilandasi oleh iman yang benar. Dengan kriteria seperti ini, diharapkan pendidikan Agama mampu mengangkat derajat para peserta didik sesuai dengan bidang ilmu yang ditekuninya. Untuk mewujudkan tujuan Pendidikan Agama di atas, bukanlah hal yang mudah. Banyak hal yang harus diperhatikan mulai dari materinya, pengelolaan atau manajemennya, metodologinya, sarana dan prasarananya, hingga guru/dosen dan peserta didiknya.

Berdasarkan usaha pemerintah untuk mengimplementasikan pendidikan Agama dan Kegamaan, makalah ini akan menganalisis kualitas muatan mata pelajaran pendidikan agama , kemudian dihubungkan dengan misi dari Peraturan Pemerintah RI Nomor. 55 Tahun 2007 tentang Pendidikan Agama dan Pendidikan Keagamaan. Maksudnya adalah ingin menjawab pertanyaan apakah kualitas muatan pendidikan agama di madrasah dan di sekolah umum ikut mendukung misi dari Peraturan Pemerintah tersebut.

Berdasarkan hal tersebut Peraturan Pemerintah terhadap pendidikan agama dan keagamaan didasarkan pada empat hal :

1) Peraturan Pemerintah tersebut dimaksudkan sebagai acuan dasar (benchmark) bagi setiap penyelenggara baik pendidikan agama maupun pendidikan keagamaan di Indonesia.

2) Peraturan Pemerintah tersebut memiliki makna yang sangat penting, sebab pendidikan agama dan pendidikan keagamaan untuk pertama kalinya diatur oleh Peraturan Pemerintah.

3) Peraturan Pemerintah ini merupakan turunan dari Undang-undang Nomor 20 tahun 2003 tentang Sistem pendidikan Nasional.

4) Dengan Peraturan Pemerintah ini pada kenyataannya menunjukkan bahwa pendidikan agama dan pendidikan keagamaan memiliki kekuatan hukum yang sangat kuat, disamping tentunya pemerintah menunjukkan perhatian yang serius.

Terkait dengan misi dan implementasi Peraturan Pemerintah tersebut, pemerintah sangat menganjurkan kepada pemegang kebijakan dan pengelola pendidikan serta masyarakat luas untuk dijadikan acuan dasar (benchnark) dalam memberikan pelayanan 
pendidikan bermutu. Dalam hal ini usaha implementasi pemerintah akan efektif dan efesien bilamana sekolah keagamaan diberikan kesempatan untuk mampu bersaing menciptakan keunggulan-keunggulan yang menjadi identitas keagamaannya. Sekolah agama akan lebih unggul karena muatan pendidikan agama jelas lebih banyak daripada sekolah-sekolah umum, ini berarti pendidikan moral yang diakandung dalam pendidikan agama lebih banyak diberikan pada keagamaan. Atau dengan kata lain keterlibatan muatan pendidikan agama dibandingkan dengan muatan pendidikan sekolah umum lebih dominan dalam mendukung misi dari Peraturan Pemerinatah nomor 55 Tahun 2007 tentang pendidikan agama dan pendidikan keagamaan. Pembahasan dalam makalah ini tidak berhenti disini, karena untuk mengukur kualitas muatan pendidikan agama harus melihat bagaimana titik tekan dan ruang waktu yang cukup yang diberikan kepada siswa, yang mana muatan mata pelajaran pendidikan agama yang diajarkan cukup padat.

Melihat data-data yang ada ternyata implementasi pemerintah hingga saat ini belum melaksanakan amanah dalam UU Pendidikan Nasional 2003, karena adanya keterbatasan ruang waktu untuk mengkaji kualitas muatan mata pelajaran tersebut, secara otomatis apa yang tercermin dalam PP N0.55 Th 2007-pun menjadi kurang mendukung tentang pendidikan agama dan pendidikan keagamaan. Padahal seharusnya dalam Peraturan Pemerintah tersebut misi antara pendidikan agama dan pendidikan keagamaan mempunyai titik tekan yang saling mendukung. Pendidikan agama adalah pendidikan yang memberikan pengetahuan dan membentuk sikap, kepribadian, dan keterampilan peserta didik dalam mengamalkan ajaran agamanya, yang dilaksanakan sekurang-kurangnya melalui mata pelajaran/kuliah pada semua jalur, jejang dan jenis pendidikan. Sementara pendidikan keagamaan adalah pendidikan yang mempersiapkan peserta didik untuk dapat mejalankan peranan yang menuntut penguasaan pengetahuan tentang ajaran agama dan/atau menjadi ahli ilmu agama dan mengamalkan ajaran agamanya.

Upaya mengimplementasikan usaha pemerintah yakni enteripoint-nya memberikan sebuah terobosan dan masukan kepada sistem pendidikan nasional maupun pada peraturan pemerintah untuk memasukan buku Kegiatan agama dan kegiatan Keagamaan bagi siswa yang harus dijadikan muatan mata pelajaran pendidikan agama di madrasah dan sekolah umum. Fungsinya adalah sebagai implementasi dan kontrol atas ilmu agama yang didapat oleh siswa dari sekolah terhadap realitas keagamaan di masyarakat. Kegiatan itu menjadi kurukulum wajib di sekolah kemudian dilaporkan dalam buku kegaitan agama dan kegiatan keagamaan.

Pendidikan Agama dan Pendidikan Keagamaan memberikan prediksi bahwa dengan mengetahui kualitas muatan pendidikan agama yang diberikan kepada siswa baik di sekolah keagamaan maupun di sekolah umum akan menentukan pada misi dari Peraturan Pemerintah tersebut, yakni pada Peraturan Pemerintah nomor 55 tahun 2007 tentang pendidikan agama dan pendidikan keagamaan yang dimaksudkan sebagai acuan dasar (benchmark) bagi setiap penyelenggara baik pendidikan agama maupun pendidikan keagamaan di Indonesia. Peraturan Pemerintah tersebut memiliki makna yang sangat penting, sebab pendidikan agama dan pendidikan keagamaan untuk pertama kalinya diatur oleh Peraturan Pemerintah. Dengan demikian Peraturan Pemerintah ini merupakan turunan dari Undang-undang Nomor 20 tahun 2003 tentang Sistem pendidikan Nasional. Kenyataan ini menunjukkan bahwa pendidikan agama dan pendidikan keagamaan memiliki kekuatan hukum yang sangat kuat, disamping tentunya pemerintah menunjukkan perhatian yan serius, namun pada dataran praktisnya kurang dari harapan, sehingga amanah dari UU Pendididikan Belum terjewantahkan dalam PP No.55 Th.2007 secara optimal.

Menurut Malik Fadjar dalam hal materi, pendidikan agama terlalu didominasi oleh 
masalah-masalah yang bersifat normatif, ritualistik dan eskatologis. Daya-daya yang dimaksud adalah daya bernafsu sebagai daya terendah, daya berani sebagai daya pertengahan, daya berfikir sebagai daya tertinggi. Dengan ketiga daya tersebut memungkin manusia untuk mengembangkan potensinya menjadi manusia yang berakhlak. Karena daya berfikir manusia akan membuatnya paten dalam dirinya dan tidak akan hancur seperti kedua daya lainnya.

\section{KESIMPULAN}

Pendidikan agama dan pendidikan keagamaan memiliki kekuatan hukum yang sangat kuat, sekolah keagamaan yang bernaung pada Kementerian Agama RI dan Sekolah umum yang bernaung pada Kementerian Pendidikan RI masih menjadi suatu keniscayaa, dan keduanya secara yuridis formal memiliki kesamaan derajat di mata hukum.

Pengembangan pendidikan agama dan keagamaan pada sekolah mengacu kepada Peraturan Pemerintah Nomor 19 Tahun 2005 tentang Standar Nasional Pendidikan (SNP) terutama pada standar isi, standar proses pembelajaran, standar pendidik dan tenaga kependidikan, serta sarana dan prasarana pendidikan. Pengembangan pendidikan keagamaan juga mengimplementasikan Peraturan Pemerintah Nomor 55 Tahun 2007 tentang Pendidikan Agama dan Pendidikan Keagamaan.

Pendidikan keagamaan pada umumnya diselenggarakan oleh masyarakat sebagai perwujudan pendidikan dari, oleh, dan untuk masyarakat. Jauh sebelum Indonesia merdeka, perguruan-perguruan keagamaan sudah lebih dulu berkembang. Selain menjadi akar budaya bangsa, agama disadari merupakan bagian tak terpisahkan dalam pendidikan. Pendidikan keagamaan juga berkembang akibat mata pelajaran/kuliah pendidikan agama yang dinilai menghadapi berbagai keterbatasan. Sebagian masyarakat mengatasinya dengan tambahan pendidikan agama di rumah, rumah ibadah, atau di perkumpulan-perkumpulan yang kemudian berkembang menjadi satuan atau program pendidikan keagamaan formal, nonformal atau informal.

\section{DAFTAR PUSTAKA}

Banks, J. 1993. Multicultural Education: Historical Development, Dimension, and Practice. Review of Research in Education.

Burnett. 1994. Varieties of Multicultural Education: An Introduction. Eric Clearinghouse on Urban Education: Digest.

Kuper, Adam \& Jessica Kuper. 2000. Ensiklopedi Ilmu-Ilmu Sosial. Jakarta: PT Raja Grafindo Persada.

Naim, Ngainun dan Achmad Sauqi. 2008. Pendidikan Multikultural: Konsep dan Aplikasi. Jokjakarta: Ar-Ruzz Media.

Suseno, Frans Magnis. 2000. "Pendidikan Pluralisme" dalam Suara Pembaharuan.

Tilaar, H.A.R. 2003. Kekuasaan dan Pendidikan: Suatu Tinjauan dari Perspektif Kultural. Magelang: Indonesia Tera.

Undang-Undang Republik Indonesia Nomor 20 Tahun 2003 Tentang Sistem Pendidikan Nasional.

Wuryanano. 2011. Mengapa Doa Saya Selalu Dikabulkan. Jakarta: Gramedia Pustaka Utama.

Yaqin, M. Ainul. Pendidikan Multikultural: Cross-Cultural Understanding untuk Demokrasi dan Keadilan. Yogyakarta: Pilar Media. 